\title{
NOVO STVARNOPRAVNO UREĐENJE LOVIŠTA
}

Doc. dr. sc. Davorin Pichler*

\author{
UDK: 347.516 \\ https://doi.org/10.30925/zpfsr.40.1.18 \\ Ur.: 21. prosinca 2018. \\ Pr.: 27. siječnja 2019. \\ Pregledni znanstveni rad
}

\section{Sažetak}

Novi Zakon o lovstvu treba stvoriti pretpostavke za uvođenje više reda u lovstvu uređivanjem odnosa između lovoovlaštenika i davatelja prava lova te preciznije urediti privatnovlasničke odnose kao pretpostavke bržega razvoja lovnog turizma i unaprjeđenja lovstva kao važne gospodarske grane. U radu se problematizira pitanje stjecanje prava vlasništva na divljači te status divljači $i$ trofeja divljači kao stvari ograničenih u prometu. Kritizira se zakonsko rješenje isključenja naknade štete za šume i šumska zemljišta kao dobara od interesa za Republiku Hrvatsku te ostvarivanje proklamiranog načela razmjernosti između ograničenja vlasničkih ovlaštenja i ostvarivanja prava lova. Otvorena pitanja o kojima bi zakonodavac trebao voditi računa pri uređenju prava lova mogu poslužiti i eventualnim de lege ferenda rješenjima vlasničkopravnih odnosa $u$ lovstvu.

Ključne riječi: lovište; vlasništvo; pravo lova; divljač; zemljište; naknada.

\section{1. $U V O D$}

Novi Zakon o lovstvu ${ }^{1}$ stupio je na snagu 17. studenog 2018. godine. Kao i u dosadašnjem zakonskom uređenju predmet zakonske regulacije gospodarenje je divljači i lovištem. Kako je predlagatelj naveo u Prijedlogu Zakona o lovstvu, ${ }^{2}$ novim zakonskim rješenjem stvaraju su pretpostavke za uvođenje više reda u lovstvu, uređivanjem odnosa između lovoovlaštenika i davatelja prava lova. ZL bi trebao preciznije urediti odnose koji se odnose na privatno vlasništvo. Vlasnicima privatnih zemljišta omogućuje se osnivanje privatnog lovišta na predmetnoj površini te omogućuje i udruživanje vlasnika zemljišta pri osnivanju privatnih lovišta. Prepoznavanje prava privatnog vlasništva u lovstvu pretpostavka je za brži razvoj

* Dr. sc. Davorin Pichler, docent, Pravni fakultet Sveučilišta J. J. Strossmayera u Osijeku; davorin.pichler@pravos.hr.

1 Zakon o lovstvu, NN br. 99/18. - dalje ZL.

2 Prijedlog Zakona o lovstvu, <https://vlada.gov.hr/UserDocsImages//Sjednice /2018/05\%20 svibnja/96\%20sjednica\%20VRH//96\%20-\%202.pdf>, očitanje 20. listopada 2018. - dalje Prijedlog ZL. 
lovnog turizma te unaprjeđenja lovstva kao važne gospodarske grane. ${ }^{3,4}$ Osnivanjem privatnog lovišta izbjegli bi se sporovi oko naknade štete na predmetnim površinama, budući da bi osnivanjem privatnog lovišta na površini zemljišta koju posjeduje kao vlasnik, vlasnik tako ustanovljenog lovišta preuzeo obveze povezane sa sprječavanjem štete od divljači na tim površinama i sam odgovarao za nastalu štetu na svojoj površini. Time bi se izbjegli prijepori koji se pojavljuju u dosadašnjoj praksi kada vlasnici poljoprivrednih površina terete ovlaštenike prava lova za nastale štete od divljači, smatrajući da nedovoljno provode mjere sprječavanja štete od divljači. U radu će naglasak biti na posebnom pravnom režimu zemljišta obuhvaćenih lovištem. ${ }^{5} \mathrm{U}$ tom smislu, analizirat će se uspostavljeno posebno stvarnopravno uređenje kao jamstvo legitimnih interesa za zaštitom divljači kao dobrom od interesa za Republiku Hrvatsku. Intenzitet posebnih ograničenja koja se nameću izvršavanju vlasničkih ovlaštenja analizirati će se s aspekta jamstva zaštite prava vlasništva. Istaknut će se i pitanja različitih vlasničkih režima u lovištu u odnosu na različite subjekte prava vlasništva: Republiku Hrvatsku, korisnike zemljišta, ovlaštenike prava lova i poljoprivrednike. Rad će analizirati i razlike u načinu stjecanja prava vlasništva na životinjama, s obzirom na njihov zakonski status (divlje životinje, divljač). Problematizirat će se koncepcija sadržaja posebnoga stvarnopravnog uređenja lovišta i pokušat će se kao rezultat dati određene smjernice i moguća rješenja za sporna pitanja de lege ferenda. U nastavku rada prikazat će se razvoj prava lova na području sadašnje Republike Hrvatske.

U nastavnim poglavljima ukazat će se na ograničenja koja proizlaze iz posebnoga stvarnopravnog uređenja lovišta, ponajprije, u odnosu na pitanja vlasništva divljači i raspolaganja trofejima i dijelovima divljači. Ukazat će se i na probleme koji nastaju kada se divljač nađe na zemljištu izvan lovišta, te u vezi s tim na novo pravno uređenje ograđivanja lovišta. Na kraju, rad će problematizirati i pitanje naknada vlasniku zemljišta za ograničenja kojima je podvrgnut na temelju ustanovljenja prava lova.

3 U tom smislu, bitni su podatci koji ukazuju na vlasničku strukturu lovišta u Republici Hrvatskoj, a prema kojima je udjel vlasništva privatnih lovišta sveden na statističku pogrešku. Prema podatcima Ministarstva poljoprivrede Republike Hrvatske u Republici Hrvatskoj ustanovljeno je 314 državnih lovišta, 772 zajednička lovišta i jedno privatno lovište. Republika Hrvatska, Ministarstvo poljoprivrede, klasa: 323-01/18-01/235, urbroj: 525-11/1349-18-2 od 3. prosinca 2018.

4 Zajednička lovišta ustanovljavaju se na onim zemljištima različitih vlasnika koji nisu mogli, na temelju odredbi ZL-a, ustanoviti državno ili privatno lovište. Ograničenja vlasničkih ovlaštenja posebnim stvarnopravnim režimom za poljoprivredna zemljišta, šumska zemljišta i lovišta sigurno su razlog za mali broj privatnih lovišta. Međutim, više je čimbenika djelovalo na prikazanu vlasničku strukturu lovišta, ponajprije potpuna dominacija društvenog vlasništva u razdoblju prije društvenih promjena devedesetih godina prošlog stoljeća. V. infra str. 5.

5 Gavella, N. i dr., Stvarno pravo - posebna pravna uređenja, Zagreb, Narodne novine, 2011., str. 555. 


\section{RAZVOJ PRAVA LOVA U HRVATSKOJ}

Kao jedna od prvih ljudskih djelatnosti lov je u najstarija vremena bio izuzet od svake zakonske regulative. ${ }^{6,7}$ Temelj lovnoga prava daju Rimljani, ${ }^{8}$ koji prepoznaju i lov kao način stjecanja vlasništva originarnim putem, jer ulovljena divlja životinja pripada onome tko ju je ubio ili uhvatio. ${ }^{9}$ Tako su u rimskim pravnim izvorima divlje životinje (ferae bestiae) tretirane kao res nullius. Svatko ih je mogao uhvatiti i steći pravo vlasništva okupacijom..$^{10}$ Međutim, lov je bilo ograničen pravom vlasništva na zemljištu, pa je vlasnik zemljišta mogao protiv onoga tko lovi na njegovom zemljištu ustati čitavim nizom pravnih lijekova. ${ }^{11}$ Kasnije, u feudalnom razdoblju, razvija se regalno pravo lova koje ostaje stoljećima na snazi u Europi. Zemljište i sve ostalo je u vlasništvu kraljeva koji diskrecijskom odlukom prenose svoja ovlaštenja na vazale, feudalce, pa tako i ovlasti lova. Za ostalo stanovništvo lov je zabranjen pod prijetnjom strogih sankcija. ${ }^{12} \mathrm{Na}$ području današnje Hrvatske, situacija je bila jednaka kao i u ostatku Europe. ${ }^{13}$ Od 16. do 19. stoljeća izvršavanje prava lova u rukama je vladara ili osoba koje je on odredio. Feudalni duh prožima i „Patent od lova“ Josipa II. iz 1786. godine. koji je bio do tada najpotpuniji lovački propis. ${ }^{14}$ Ukinućem kmetstva, 1848. godine, lov se vezuje za vlasništvo nad zemljom. ${ }^{15}$ Time se dokida stari regalni

6 Gardaš, M. i Haman, D., Regalno pravo lova i lovno zakonodavstvo u Hrvatskoj kroz povijest, Zbornik radova sa naučnog skupa, Historija države i prava BiH - izazovi i perspektive, Tuzla, 2017., str. 283.

7 Međutim, već od 2500. godine u Gornjoj Mezopotamiji lov više nije djelatnost kojom se prehranjuje obitelj, već je djelatnost društvenoga prestiža više klase. Više nije dopušteno svima loviti, već tu djelatnost aristokracija preuzima u svoje ruke. Gardaš, M. i Alebić, T., The introduction of a dominant legal system for the regulation of hunting in Croatia in the second half of the 19th century, 7. Međunarodni znanstveni simpozij gospodarstvo istočne Hrvatske vizija i razvoj, Osijek, 2018., str. 29.

8 Loc. cit.

9 Romac, A., Rječnik rimskog prava, Zagreb, Informator, 1989., str. 382.

10 Ibid., str. 43.

11 Gardaš, M., Haman, D, op. cit., str. 284.

12 Gardaš, M., Alebić, T., op. cit., str. 29.

13 Lov kao zabava plemstva preuzima se s njemačkih prostora, osobito austrijskog plemstva. Kolar-Dimitrijević, M. i Wagner, E., Lov i plemstvo u Hrvatskoj i Slavoniji, Ekonomska i Ekohistorija: časopis za gospodarsku povijest i povijest okoliša, vol. V, 1/2009, str. 45.

14 Bajt-Vučevac, V., Alegro, A., Žvorc, Z., Razvoj hrvatskog zakonodavstva o lovu, Stočarstvo: Časopis za unapređenje stočarstva, vol. 50, 3/1996, str. 220.

15 Nakon toga, u prvo vrijeme, bilo je dopušteno svima loviti na zemljištu koje nije u privatnom vlasništvu. Vrlo brzo se od te prakse odustalo budući da je pretjerani lov ozbiljno ugrozio populaciju divljači. Gardaš, M., Alebić, T., op. cit., str. 32. 
sustav lova i 1870. godine uvodi dominalni sustav lova. ${ }^{16,17}$ Novi sustav razlikuje privatna lovišta koja su se mogla uspostaviti na zemljištu vlasnika koji je u komadu imao 200 katastarskih rali zemlje, te općinska lovišta koja su se ustrojavala također na minimalno 200 katastarskih rali zemlje. Općinska lovišta su putem javne dražbe kotarski sudovi davali u zakup najboljem ponuđaču na vrijeme od 10 do 12 godina za bavljenje lovom. Ovim ustrojem lov postaje dostupan najširem krugu građana, a ne kao do tada isključivo privatnim vlasnicima zemljišta. ${ }^{18}$ Dominalni sustav lova koji je uveden 1870. godine zadržan je do danas. Nizom kasnijih zakona nastojala su se urediti različita važna pitanja lovstva (osnivanje lovačkih društava, zabrane upotrebe različitih lovačkih metoda (stupice), uporaba lovačkih pasa i sl.). ${ }^{19}$ Godine 1947. lov je u tadašnjoj Jugoslaviji zakonski reguliran na saveznoj razini, a 1949. godine Hrvatska donosi republički Zakon o lovu. Lovišta su podijeljena na „državna lovišta“ i „društvena lovišta“ kojima upravljaju lovačke organizacije. S oba segmenta upravlja republički centar. ${ }^{20}$ Sabor Republike Hrvatske republičkim Zakonom o lovstvu iz 1973. godine divljač proglašava društvenom imovinom od posebnog interesa. ${ }^{21}$ Raspadom Jugoslavije, u Republici Hrvatskoj donesen je 1994. godine Zakon o lovu, ${ }^{22}$ koji predstavlja raskid sa socijalističkim uređenjem lovstva i ponovnu reinkorporaciju, tzv. dominalnog sustava lovstva. ${ }^{23}$ Novo zakonsko rješenje gospodarenja lovištima pokušalo se pronaći u Zakonu o lovstvu iz 2005. godine, ${ }^{24}$ a koji je nakon 13 godina napokon zamijenjen aktualnim ZL-om.

\section{POSEBNO STVARNOPRAVNO UREĐENJE}

Norme općega stvarnopravnog uređenja imaju za cilj regulaciju odnosa $u$ pogledu bilo kojih objekata stvarnih prava, tretirajući ih u načelu jednako. Posebna stvarnopravna uređenja uređuju te odnose $\mathrm{u}$ pogledu neke određene vrste stvari,

16 Kriza iz 1873. godine, zbog sloma dionica na bečkoj burzi, onemogućila je gospodarski oporavak plemstva u Hrvatskoj. Oni koji nisu uspjeli organizirati svoje veleposjede na dohodovnoj razini počeli su krčiti šume i prodavati drvnu masu velikim tvrtkama. Ukinućem kmetstva, plemstvo se stalno nalazi u krizi osobito u sjeverozapadnoj Hrvatskoj gdje gotovo nije moguće urediti posjed na dohodovnoj robno-novčanoj osnovi. Velikaši zbog toga počinju razmišljati o mogućnosti davanja lovišta u zakup. Lov više nije zabava već ozbiljan posao s vrlo malo dobiti. Kolar-Dimitrijević, M. i Wagner, E., op. cit., str. 45-54.

17 Začetak lovnoga zakonodavstva pronalazimo u propisima iz 18. stoljeća kao, npr. član 22. Trećeg dekreta Hrvatsko-Ugarskog kralja Karla III. Iz 1729. godine, čl. 11. Vojnog regimenta Marije Terezije iz 1751. godine, te pojedini paragrafi u marijaterezijanskim urbarima. BajtVučevac, V., Alegro, A., Žvorc, Z, op. cit., str. 219.

18 Gardaš, M., Haman, D., op. cit., str. 295-296.

19 Tako se u Kraljevini SHS 1931. godine donosi Zakon o lovu kojim se ograničava pravo lova i za vlasnika zemljišta koji mora posjedovati 200 ha neprekinutog zemljišta. Time se pruža zaštita divljači koja bi bila ugrožena pravom lova svakog vlasnika na svojoj parceli. Bajt-Vučevac, V., Alegro, A., Žvorc, Z., op. cit., str. 223.

20 Loc. cit.

21 Ibid., str. 224.

22 Zakon o lovu, NN, br. 10/94., 29/99., 76/99., 14/01., 4/02.

23 Bajt-Vučevac, V., Alegro, A., Žvorc, Z., op. cit., str. 224.

24 Zakon o lovstvu, NN, br. 140/05., 75/09., 153/09., 14/14., 21/16., 41/16., 62/17. - dalje ZL-05. 
obilježene nekom njihovom funkcijom ili namjenom. ${ }^{25}$ Kada je za neku vrstu stvari potrebno posebno stvarnopravno uređenje, trebalo bi pažljivo prosuditi koji bi mu sadržaj bio primjeren. Sadržaj posebnoga pravnog uređenja može biti primjeren samo ako je njime uspostavljen ispravan razmjer između šireg interesa, koji se tim posebnim uređenjem štiti i onih prava koja se u tom interesu njime ograničavaju. Tu je potrebna ispravna primjena ustavnog pravila razmjernosti, prema kojem svako ograničenje prava mora biti razmjerno naravi potrebe za ograničenjem u svakom pojedinom slučaju. ${ }^{26}$ Pravilo razmjernosti ograničenja sloboda i prava daje članak 16. Ustava Republike Hrvatske. ${ }^{27}$ Njime se određuje da se slobode i prava mogu ograničiti samo zakonom da bi se zaštitila sloboda i prava drugih ljudi te pravni poredak, javni moral i zdravlje. Svako ograničenje slobode ili prava mora biti razmjerno naravi potrebe za ograničenjem u pojedinom slučaju. Također, članak 33. stavak 3. Zakona o vlasništvu i drugim stvarnim pravima ${ }^{28}$ određuje pravo na naknadu vlasniku stvari koji je podvrgnut ograničenjima u odnosu na tu stvar, a koja inače ne terete ostale vlasnike takvih stvari. ${ }^{29}$

Da bi ograničenje prava vlasništva, određeno posebnim stvarnopravnim režimom bilo dopušteno, s pozicije citiranog određenja Ustava $\mathrm{RH}$, mora se raditi o stvarima čiji je način uporabe i iskorištavanja određen zakonom, te da je ograničenje vlasništva razmjerno naravi potrebe za ograničenjem..$^{30} \mathrm{ZL}$ u članak 3. stavak 1. divljač određuje kao dobro od interesa za Republiku Hrvatsku koje ima njenu osobitu zaštitu. Također, ZL određuje da je ustanovljenje lovišta u interesu Republike Hrvatske. ${ }^{31}$ Dakle, poseban pravni režim uspostavlja se u odnosu na zemljišta koja u posebnom postupku budu proglašena lovištem, kako bi se osigurala zaštita divljači.$^{32}$ $\mathrm{U}$ tom smislu, zakonodavac je iskoristio svoje ovlaštenje iz članak 52. Ustava RH i posebnim stvarnopravnim uređenjem pružio osobitu zaštitu dobru od interesa za Republiku Hrvatsku. ${ }^{33}$ Zakonodavac je odredio i naknadu vlasnicima zemljišta bez prava lova za ograničenja kojima su podvrgnuti posebnom zakonskom regulacijom. ${ }^{34}$

25 Gavella, N., i dr., Stvarno pravo - posebna, str. 5-6.

26 Ibid., str. 32.

27 Ustav Republike Hrvatske, NN, br. 56/90., 135/97., 8/98. (pročišćeni tekst), 113/00., 124/00. (pročišćeni tekst), 28/01., 41/01. (pročišćeni tekst), 55/01. (ispravak), 76/10., 85/10. (pročišćeni tekst), 5/14. (Odluka Ustavnog suda Republike Hrvatske) - dalje Ustav RH.

28 Zakon o vlasništvu i drugim stvarnim pravima, NN, br. 91/96., 68/98., 137/99., 22/00., 73/00., 129/00., 114/01., 79/06., 141/06., 146/08., 38/09., 153/09., 143/12., 152/14., 81/15. (pročišćeni tekst), 94/17. (pročišćeni tekst). - dalje ZV.

29 Citirani članak ZV-a u cijelosti određuje da ako je vlasnik glede neke svoje stvari podvrgnut ograničenjima radi zaštite interesa i sigurnosti Republike Hrvatske, prirode, ljudskoga okoliša ili zdravlja ljudi, koja od njega, ali ne i od svih ostalih vlasnika takvih stvari, zahtijevaju težu žrtvu, ili ga inače dovode u položaj nalik na onaj u kojem bi bio da je provedeno izvlaštenje - on ima pravo na naknadu kao za izvlaštenje.

30 Gavella, N. i dr., Stvarno pravo, Zagreb, Narodne novine, 2007., str. 368.

31 Čl. 3. st. 2. ZL.

32 Čl. 20. ZL određuje da divljač uživa posebnu zaštitu tako što na onim površinama na kojima je zabranjeno ustanovljivanje lovišta, korisnik te površine je dužan štititi divljač.

33 Gavella, N. i dr., Stvarno pravo, str. 367.

34 U tom smislu čl. 19. ZL određuje da se vlasniku zemljišta bez prava lova određuje naknada za ograničenja kojima je podvrgnut u ostvarivanju prava lova drugih osoba. Kriterije za 
Opseg, odnosno razmjernost ograničenja vlasništva koje postavlja ZL, te pravičnost naknade vlasnicima kao kompenzacije za podvrgavanje ograničenjima, biti će nastavno analizirani $\mathrm{u}$ radu.

\section{VLASNIČKOPRAVNI REŽIMI U LOVIŠTU}

I zakonsko uređenje prije aktualnog ZL-a omogućavalo je da se lovišta mogu ustanoviti na svakom zemljištu u privatnom ili javnom vlasništvu, osim na zemljištima kojima je posebnim propisom ili posebnim aktom o određenju namjene zemljišta, izričito zabranjen lov. ${ }^{35,36}$ Nakon što je lovište ustanovljeno, ne mijenja se vlasničkopravni režim zemljišta na kojem je ono ustanovljeno. Međutim, poseban režim uspostavlja se u odnosu na vršenje vlasničkih ovlaštenja radi učinkovitijeg gospodarenja lovištem u korist nositelja prava lova. ${ }^{37,38,39}$ Dakle, dva različita prava, vlasništvo i pravo lova, postoje na istom objektu (zemljištu) i mogu međusobno konkurirati. Inače, ta su dva prava načelno neovisna jedna od drugog. Međutim, dok pravo vlasništva zemljišta, u pravilu, ne utječe na pravo lova, ovlaštenje osobe da se koristi pravom lova podvrgava vlasnika ograničenjima vlasničkih ovlaštenja.

Stoga će nastavno biti istaknuta neka pitanja o posebnom vlasničkopravnom režimu koji je uspostavio ZL. I sam zakonodavac je, u Prijedlogu ZL-a, naglasio potrebno preciziranje zakonskih odredbi koje se odnose na privatno vlasništvo. Prije svega, predlaganjem mogućnosti osnivanja privatnog lovišta izbjegava se mogućnost sporova oko naknade štete na predmetnim površinama, budući da bi osnivanjem privatnog lovišta na površini zemljišta koju posjeduje kao vlasnik, vlasnik tako ustanovljenog lovišta preuzeo obveze vezane za sprječavanje štete od divljači na tim površinama i sam odgovarao za štetu nastalu na svojoj površini. Time bi se izbjegli

određivanje i raspored naknade daje čl. 31. ZL-a, određujući da vlasnik zemljišta bez prava lova ima pravo na $10 \%$ sredstava od naknade za pravo lova, razmjerno površini koja je obuhvaćena lovištem za koje se uplaćuje naknada za pravo lova, preko proračuna županija i Grada Zagreba, na čijem je području ustanovljeno lovište. Čl. 41. st. 3. ZL određuje da vlasnik zemljišta bez prava lova ima pravo u tom omjeru i na sredstva naknade za koncesiju prava lova.

35 Gavella, N. i dr., Stvarno pravo - posebna, str. 556.

36 ZL u čl. 11. st. 2. zabranjuje ustanovljenje lovišta na miniranim površinama, na moru i ribnjacima, u rasadnicima i nasadima voćaka, vinove loze, ljekovitog i drugog bilja te pašnjacima ako su ograđeni ogradom koja sprječava prirodnu migraciju dlakave divljači, na zaštićenim dijelovima prirode ako je posebnim propisima u njima zabranjen lov, na javnim cestama i drugim javnim površinama, na građevinskom području, na vojnim lokacijama, na drugim površinama na kojima je aktom o proglašenju njihove namjene zabranjen lov.

37 Gavella N. i dr., Stvarno pravo - posebna, str. 556.

38 Čl. 7. st. 1. toč. 19. ZL određuje pravo lova kao ovlast da se na određenoj površini zemljišta i voda provode radnje uzgoja, zaštite, lova i korištenja divljači i njezinih dijelova.

39 ZL ne određuje pravnu narav prava lova. ZL navodi samo da se gospodarenjem divljači postiže ispunjavanje gospodarske, turističke i rekreativne funkcije i zaštita biološke raznolikosti i ekološke ravnoteže (čl. 4.), da vlasnik privatnog lovišta može pravo lova u lovištu dati u zakup (čl. 33.), te da je dopušteno baviti se komercijalnim lovom. To ukazuje da je pravo lova subjektivno pravo koje obuhvaća različita ovlaštenja od kojih neka imaju imovinski karakter. Nositelj prava lova ostvarivanjem svojih ovlaštenja može ostvarivati i gospodarsku dobit, pa pravo lova ima i imovinsku vrijednost. Gavella, N. i dr., Stvarno pravo - posebna, str. 563. 
prijepori iz dosadašnje prakse kada su vlasnici poljoprivrednih površina teretili ovlaštenike prava lova za štete nastale od divljači, smatrajući da nedovoljno provode mjere sprječavanja šteta od divljači ${ }^{40}$ Naglasit će se i vlasničkopravna pitanja iz zakonskog uređenja koja se odnose na različite vlasničkopravne režime u lovištima, ograđivanje lovišta, odnosno, označavanje dosega vlasnikove pravne vlasti, pitanje ostvarivanja naknade za ograničenja vlasničkih ovlaštenja vlasnicima zemljišta na čijim površinama su ustanovljena lovišta te pitanje stjecanja vlasništva divljači.

\subsection{Konkurencija posebnih vlasničkih režima}

Kao kuriozitet može se istaknuti okolnost da se na području lovišta susreću različiti vlasnički režimi, svaki s posebnim stvarnopravnim uređenjem. Tako je moguće da na površini lovišta postoji poljoprivredno zemljište koje je na temelju Zakona o poljoprivredom zemljištu ${ }^{41}$ određeno kao dobro od interesa za Republiku Hrvatsku i ima njezinu osobitu zaštitu, ${ }^{42}$ što određuje i članak 52. Ustava $\mathrm{RH} \cdot{ }^{43} \mathrm{Na}$ površini lovišta može postojati i šuma koja je Zakonom o šumama ${ }^{44}$ isto tako, određena dobrom od interesa za Republiku Hrvatsku i uživa njenu osobitu zaštitu. ${ }^{45,46} \mathrm{~S}$ obzirom na navedeni vlasničkopravni režim, nužno je istaknuti ograničenje da su privatna lovišta u vlasništvu stranih fizičkih ili pravnih osoba ako je lovište ustanovljeno na zemljištu koje je prema namjeni poljoprivredno zemljište, budući da članak 2. stavak 2. ZPZ-a određuje da nositeljima prava vlasništva na poljoprivrednom zemljištu ne mogu biti strane pravne i fizičke osobe. ${ }^{47,48}$ Ova ograničenja mogu biti i u koliziji s intencijom zakonodavca za stvaranje pretpostavki za brži razvoj lovnog turizma, utvrđivanje prava i obveza vlasnika poljoprivrednih površina i lovoovlaštenika, te unaprjeđenja lovstva kao važne gospodarske grane Republike Hrvatske koja je konkurentna na europskom tržištu. ${ }^{49}$

Slična situacija proizlazi na temelju odredbi ZOŠ-a kojim se zabranjuje gospodarska uporaba prirodnih dobara u zaštićenim šumama. ${ }^{50} \mathrm{Od}$ cijelog niza ograničenja vlasničkih ovlaštenja kojima su podvrgnuti vlasnici zemljišta na kojima je

40 Prijedlog ZL, str. 5-6.

41 Zakon o poljoprivrednom zemljištu, NN br. 20/18. - dalje ZPZ.

42 Čl. 2. st. 1. ZPZ.

43 Klarić, P. i Vedriš, M., Građansko pravo, Zagreb, Narodne novine, 2006., str. 519.

44 Zakon o šumama, NN br. 68/18. - dalje ZOŠ.

45 Čl. 2. st. 1. ZOŠ.

46 Posebno stvarnopravno uređenje za šume također proizlazi iz čl. 52. Ustava RH koji šume određuje kao dobro od interesa za Republiku Hrvatsku. Gavella, N. i dr., Stvarno pravo posebna, str. 159.

47 Međutim, uz uvjet reciprociteta, strane fizičke i pravne osobe mogu stjecati pravo vlasništva na poljoprivrednom zemljištu nasljeđivanjem. Čl. 2. st. 3. ZPZ.

48 Čl. 16. st. 1. ZL određuje da privatna lovišta ustanovljuje odlukom ministar nadležan za poslove lovstva na zemljištu u vlasništvu pravnih ili fizičkih osoba.

49 Prijedlog ZL, str. 3.

50 Čl. 22. st. 8. i 9. ZOŠ određuje zaštićene šume kao šume koje, uz očuvanje i unaprjeđenje njihovih općekorisnih funkcija, primarno služe za zaštitu tla, voda, naselja, objekata i druge imovine, a radovi u njima provode se uz uvažavanje njihove primarne namjene. 
ustanovljeno lovište treba istaknuti dužnost provedbe lovnogospodarskog plana ${ }^{51}$ koji mora biti u skladu sa šumskogospodarskim planom, ${ }^{52}$ uvjetima i načinom korištenja poljoprivrednog zemljišta, prostornim planovima, odnosno posebnim propisima iz područja prostornog uređenja, zaštite okoliša i prirode te međunarodnim ugovorima kojih je Republika Hrvatska stranka iz područja lova i zaštite prirode, kao i propisima Europske unije kojima se uređuje očuvanje divljih vrsta i prirodnih staništa..$^{53,54}$

Ako je lovište ustanovljeno na poljoprivrednom zemljištu, vlasnici i posjednici poljoprivrednog zemljišta dužni su obrađivati poljoprivredno zemljište primjenjujući agrotehničke mjere ${ }^{55,56}$ koje je propisao ministar nadležan za poljoprivredu. ${ }^{57}$ Treba ukazati i na okolnost da postoji vrsta poljoprivrednog zemljišta koje se ne može koristiti u nepoljoprivredne svrhe. Radi se o osobito vrijednom obradivom i vrijednom obradivom poljoprivrednom zemljištu. ${ }^{58}$ Mjerila za utvrđivanje osobito vrijednog obradivog i vrijednog obradivog poljoprivrednog zemljišta propisuje pravilnikom ministar nadležan za poljoprivredu. ${ }^{59}$ Nije teško zamisliti situaciju da nakon što lovište bude ustanovljeno na određenom poljoprivrednom zemljištu ono bude utvrđeno kao osobito vrijedno obradivo ili vrijedno obradivo poljoprivredno zemljište. ${ }^{60,61} \mathrm{U}$

51 Čl. 7. st. 1. toč. 11. ZL određuje lovnogospodarski plan kao program uzgoja i zaštite divljači i njihove revizije.

52 Čl. 27. st. 1. ZOŠ određuje šumskogospodarski plan kao temeljni dokument za gospodarenje i korištenje šuma i šumskih zemljišta na području Republike Hrvatske, koji utvrđuje uvjete za održivo gospodarenje šumama i šumskim zemljištem i zahvate na tom prostoru, potreban opseg uzgoja i zaštite šuma, mogući stupanj iskorištenja te uvjete za gospodarenje životinjskim svijetom.

53 Čl. 48. st. 1. ZL.

54 Čl. 43. st. 1. i 2. ZL određuje da se pravo lova izvršava kao pravo i dužnost provedbe lovnogospodarskog plana. Bez odobrenoga lovnogospodarskog plana nije dopušteno izvršavanje prava lova.

55 Agrotehnika obuhvaća sve zahvate koji se odnose na uzgoj poljoprivrednih kultura. Agrotehničke mjere se odnose na pojedine intervencije u agrotehničkom kompleksu, sve prostorne i vremenske zahvate kojima se postiže što povoljniji razvoj poljoprivrednih kultura. Poljoprivredna enciklopedija, Jugoslavenski leksikografski zavod, Zagreb, 1967., str. 17.

56 Pod agrotehničkim mjerama smatraju se: minimalna razina obrade i održavanja poljoprivrednog zemljišta, sprječavanje zakorovljenosti i obrastanja višegodišnjim raslinjem, suzbijanje biljnih bolesti i štetnika, korištenje i uništavanje biljnih ostataka, održavanje organske tvari u tlu, održavanje povoljne strukture tla, zaštita od erozije. Čl. 3. Pravilnika o agrotehničkim mjerama, $\mathrm{NN}$ br. $142 / 13$.

57 Čl. 4. st. 6. i 7. ZPZ.

58 Čl. 22. st. 1. i 2. ZPZ određuje kao osobito vrijedno obradivo poljoprivredno zemljište najkvalitetnije površine poljoprivrednog zemljišta predviđene za poljoprivrednu proizvodnju koje oblikom, položajem i veličinom omogućavaju najučinkovitiju primjenu poljoprivredne tehnike. Kao vrijedno obradivo poljoprivredno zemljište određuje površine poljoprivrednog zemljišta primjerene za poljoprivrednu proizvodnju po svojim prirodnim svojstvima, obliku, položaju i veličini.

59 Čl. 22. st. 5. ZPZ.

60 Hrvatski centar za poljoprivredu, hranu i selo utvrđuje koje se poljoprivredno zemljište smatra osobito vrijedno obradivo i vrijedno obradivo poljoprivredno zemljište, ako ima bitnih promjena u odnosu na postojeće stanje, odnosno pokazatelje na jednom širem području. Čl. 4. st. 4. ZPZ.

61 Treba istaknuti da poljoprivredna inspekcija u provođenju inspekcijskog nadzora osobito nadzire koristi li se poljoprivredno zemljište u nepoljoprivredne svrhe, ako takvo korištenje 
tom smislu, posebno je važno da u postupku ustanovljenja lovišta izrada i provedba lovnogospodarske osnove ${ }^{62}$ mora biti usklađena sa šumskogospodarskim planovima te uvjetima i načinom korištenja poljoprivrednog zemljišta. ${ }^{63}$

\subsection{Vlasništvo divljači}

Osim konkurencije različitih posebnih vlasničkih režima na zemljištu na kojem je ustanovljeno lovište važno je istaknuti i pitanje vlasništva nad različitim životinjskim vrstama koje se nalaze na zemljištu na kojem je ustanovljeno lovište. U odnosu na divljač ${ }^{64}$ nema zakonske odredbe koja nedvosmisleno uređuje pravo vlasništva na divljači. Naime, članak 3. ZL-a određuje samo da je divljač dobro od interesa za Republiku Hrvatsku i da ima njenu osobitu zaštitu. Iz dikcije članka 5. stavka 1. ZL$\mathrm{a}^{65}$ može se zaključiti da divljač predstavlja res nullius, no i da za stjecanje prava vlasništva na divljači okupacijom vrijedi poseban zakonski režim. Članak 74. stavak 1. ZL-a određuje da ulovljena, ranjena i uginula divljač te njezini dijelovi pripadaju lovoovlašteniku, a na površini na kojoj je zabranjeno ustanovljivanje lovišta korisniku te površine. Dakle, isključivo pravo stjecanja u vlasništvo divljači prisvojenjem imaju ovlaštenik prava lova i korisnik zemljišta na kojem je zabranjeno ustanovljivanje lovišta. ${ }^{66}$ Te osobe stječu pravo vlasništva divljači ulovom, ranjavanjem i uginućem divljači ${ }^{67}$ Ako bi netko drugi izvršio akt prisvajanja divljači, time bi u vlasništvo divljač stekao onaj tko je ovlaštenik prava lova, odnosno korisnik zemljišta na kojem je zabranjeno ustanovljivanje lovišta. Prisvojitelj bi stekao samo posjed, no ne i vlasništvo divljači ${ }^{68}$ Jasna i nedvosmislena zakonska odredba kojom se utvrđuje vlasništvo nad divljači, de lege ferenda, pridonijela bi pravnoj sigurnosti pogotovo u slučajevima kada od pitanja tko je vlasnik divljači ovisi sudska odluka u postupcima

nije dopušteno. Poljoprivredni inspektor zapisnikom utvrđuje nepravilnosti i nedostatke i donosi rješenje u kojem određuje rok za njihovo otklanjanje, odnosno određuje propisanu upravnu mjeru. Protiv rješenja poljoprivrednog inspektora ne može se izjaviti žalba, ali se može pokrenuti upravni spor. Čl. 87. st. 1. i 88. st. 1. i 4. ZPZ.

62 Čl. 44. st. 1. ZL određuje da je lovnogospodarska osnova planski akt kojim se detaljno uređuje gospodarenje, uzgoj, zaštita, lov i korištenje određenom divljači i lovištem za razdoblje od deset lovnih godina s mogućnošću staništa te brojnosti i stanjem populacije divljači koja se uzgaja u otvorenim i ograđenim lovištima.

63 Čl. 48. st. 1. ZL.

64 Definiciju divljači ne daje ZL već u čl. 9. taksativno navodi koje se životinjske vrste smatraju divljači (kao temeljnu podjelu ZL razlikuje: krupnu divljač i sitnu divljač, koju se dijeli na dlakavu i pernatu divljač). Međutim, definiciju divljači sadrži ZOŠ koju određuje kao posebnim zakonom određene životinjske vrste koje slobodno žive u prirodi, na površinama namijenjenim za uzgoj ili intenzivni uzgoj i razmnožavanje u svrhu lova i korištenja. Čl. 8. st. 1. toč. 3. ZOŠ.

65 Citirani članak određuje da se ZL primjenjuje na divljač odnosno ZL-om određene životinjske vrste koje slobodno žive u prirodi, na površinama namijenjenim za uzgoj ili intenzivni uzgoj i razmnožavanje u svrhu lova i korištenja.

66 Štoviše, ostalim osobama ZL zabranjuje i svako premještanje, prenošenje i prevoženje divljači.

Čl. 74. st. 2. i 3. ZL.

67 Čl. 74. st. 1. ZL.

68 Gavella, N. i dr., Stvarno pravo, str. 510. 
odštetnih zahtjeva za divljač. ${ }^{69}$

Osim divljači, u lovištu se nalaze i druge životinje. Tako ZL prepoznaje pojam „podivljale životinje domaćih vrsta“ koje određuje kao domaće životinjske vrste koje žive slobodno u prirodi i koje je vlasnik napustio i ostavio bez odgovarajućeg nadzora. ${ }^{70} \mathrm{U}$ odnosu na podivljale životinje domaćih vrsta radi zaštite i očuvanja biološke i ekološke ravnoteže staništa, divljači i divlje faune i flore, Ministarstvo nadležno za poslove lovstva određuje načine trajnog uklanjanja. ${ }^{71}$ Također, ZL spominje i ,druge životinjske vrste“.$^{72} \mathrm{U}$ odnosu na određenje divljih životinja koje nisu divljač lex specialis je Zakon o zaštiti prirode ${ }^{73}$ koji određuje pojam divlje vrste ${ }^{74}$ i njihovu sistematizaciju. Divlje životinje ničije su stvari koje svatko može steći u vlasništvo prisvojenjem. ZZP postavlja određena ograničenja ${ }^{75}$ i zabrane i propisuje kazne, no to ne utječe na građanskopravni učinak prisvojenja. ${ }^{76,77}$

\subsubsection{Divljač na tuđem zemljištu}

ZL ne sadrži posebne odredbe o načinu postupanja u slučajevima kada je divljač dospjela na tuđu nekretninu. U tom smislu, za navedene situacije dolazila bi u obzir primjena odredbi ZV-a kojima se uređuje pristup na tuđe. Dakle, temeljem čl. 106. ZV-a, ako bi na tuđu nekretninu dospjela divljač, onaj čija je divljač može, u primjernom roku, pristupiti na tuđe zemljište kako bi ju uzeo nazad. Pritom se ne mora od vlasnika nekretnine tražiti posebno dopuštenje, a ukoliko bude zatraženo, vlasnik nekretnine ga je dužan dati. ${ }^{78}$ Vlasnik nekretnine može zabraniti pristup na

69 Ovo pitanje je od akutnog značaja upravo u vezi s postupcima odgovornosti za štetu u prometnim nesrećama u kojima sudjeluje vozilo i divljač. U praksi je postavljeno pitanje odgovara li se po načelu subjektivne ili objektivne odgovornosti? Na pitanje je li divljač opasna stvar, sudska praksa nije dala jedinstven odgovor, jer ne stavlja znak jednakosti između kune ili zeca i jelena i vepra. Od rješenja pitanja je li divljač opasna stvar ovisi primjena načela objektivne odgovornosti. Također, od utvrđivanja je li divljač vlasništvo Republike Hrvatske ili lovoovlaštenika zavisi rješenje pitanja tko ima pravo podnijeti odštetni zahtjev za divljač. Savić, Š., Pitanje naknade štete možemo promatrati dvosmjerno, Lovački vjesnik, 4-5/2018., str. 36.

70 Čl. 7. st. 1. toč. 18 . ZL.

71 Čl. 63. st. 3. toč. 7. ZL.

72 Čl. 52. i čl. 54. st. 1. toč. 8. ZL.

73 Zakon o zaštiti prirode, NN br. 80/13., 15/18. - dalje ZZP.

74 Čl. 9. st. 1. toč. 4. ZZP određuje da je divlja vrsta ona koja nije nastala pod utjecajem čovjeka kao posljedica umjetnog odabiranja ili genetske modifikacije nasljednog materijala tehnikama moderne biotehnologije. ZZP.

75 Tako čl. 64. st. 1. i st. 4. ZZP određuje da je za sakupljanje, odnosno uzimanje iz prirode u svrhu prerade i/ili prodaje zavičajnih divljih vrsta pravna i fizička osoba dužna ishoditi dopuštenje Ministarstva nadležnog za zaštitu prirode. Zavičajne divlje vrste otkupljene od fizičkih ili pravnih osoba koje nisu nositelji dopuštenja ne smatraju se zakonito stečenim.

76 Gavella, N. i dr., Stvarno pravo, str. 509.

77 U tom smislu, ukoliko nedostaje valjani pravni temelj za stjecanje prava vlasništva na divljoj životinji, kao alternativni način stjecanja prava vlasništva ostaje putem instituta dosjelosti. Naravno, uz uvjet da ne bude osporeno poštenje stjecatelja.

78 Gavella, N. i dr., Stvarno pravo, str. 659. 
svoju nekretninu jedino ako bi stvar sam vratio bez odgađanja posjedniku. ${ }^{79} \mathrm{U}$ odnosu na odredbe ZL-a kojima se određuje da lovoovlaštenik pravo vlasništva nad divljači stječe ulovom, ranjavanjem i uginućem, može se zaključiti da ako je divljač koja je dospjela na tuđu nekretninu ranjena, vlasnik divljači je lovoovlaštenik. Kada vlasnik nekretnine uhvati ranjenu divljač, on postaje neposrednim posjednikom divljači koji posjedovne čine izvršava za posrednog posjednika - lovoovlaštenika. Međutim, i u slučaju kada se ne radi o ranjenoj divljači, hvatanjem divljači od strane vlasnika nekretnine on također ne postaje njezinim vlasnikom, već činom hvatanja vlasnik divljači postaje lovoovlaštenik.

Na temelju članka 106. stavka 3. ZV-a vlasnik nekretnine za štetu koja mu je nastupila od životinje, od njenog uzimanja i vraćanja ili su u vezi s tim za vlasnika nekretnine nastali troškovi koji su bili nužni, on ima pravo zadržati životinju ${ }^{80}$ sve dok mu šteta i troškovi ne budu u cijelosti namireni. Međutim, ZL propisuje vrste šteta koje nastupaju od divljači, ali se ne nadoknađuju. ${ }^{81,82} \mathrm{U}$ tom smislu, za vlasnika nekretnine ne nastaje ni pravo zadržanja radi osiguranja naknade takve štete od divljači.

Važno je kritički osvrnuti se na konačno prihvaćenu formulaciju iz čl. 81 . ZL-a po kojoj se ne nadoknađuje šteta koju divljač počini ako je nastala na površini manjoj od $5 \%$ ukupne površine tehnološke cjeline sukladno posebnom propisu. Takvo zakonsko uređenje može se kvalificirati kao nepotrebno kompliciranje zakonodavca u odnosu na nomotehnički jasnu formulaciju iz prijedloga u izvješću Odbora za poljoprivredu o Prijedlogu ZL-a koje može imati za posljedicu pravnu nesigurnost u postupcima za naknadu štete od divljači. Također, možemo se upitati i o dosegu odredbe iz članka 106. stavka 3. ZV-a, čiji je ratio legis upravo stvarno pojačanje pravnog položaja vjerovnika, ako ZL određuje da se određena vrsta šteta koju divljač počini uopće ne nadoknađuje? Ovo uređenje može se posebno kritizirati

79 Čl. 106. st. 2. ZV.

80 Pravo zadržanja, kao oblik stvarnog pojačanja obveznopravnog odnosa, je ovlaštenje vjerovnika da dužnikovu stvar, koja se nalazi u njegovim rukama, zadrži do ispunjenja tražbine te da se, ako ispunjenje izostane, naplati iz njezine vrijednosti. Pravo zadržanja nastaje ex lege, u tom slučaju na temelju citirane odredbe ZV-a. Vjerovnik svoje ovlaštenje naplatiti se iz vrijednosti zadržane stvari, ostvaruje na isti način kao založni vjerovnik. Klarić, P. i dr., op. cit., str. $432-$ 433.

81 Tako čl. 81. ZL određuje da se ne nadoknađuje šteta koju divljač počini: ako je nastala šteta na površini manjoj od $5 \%$ ukupne površine tehnološke cjeline sukladno posebnom propisu, na površinama na kojima vlasnik ili korisnik zemljišta nije poduzeo mjere i radnje za sprječavanje šteta u lovištima, stoci na površinama na kojima je posebnim propisom zabranjen pristup i ispaša stoke, na neoznačenim i neregistriranim domaćim životinjama, kao ni šteta na domaćim životinjama koje su bez nadzora puštene u prirodu, na neograđenim višegodišnjim nasadima, na šumi i šumskom zemljištu, korisnicima zemljišta koji protupravno koriste zemljište.

82 Formulaciju iz čl. 81. st. 1 ZL-a treba tumačiti da se predloženih 5\% vrijednosti poljoprivredne proizvodnje ne odnosi na ukupnu poljoprivrednu proizvodnju oštećenika, nego samo na parcelu koja je pretrpjela štetu od divljači. Takav je prijedlog i u izvješću Odbora za poljoprivredu o Prijedlogu ZL-a. Izvorno, Prijedlog ZL-a odnosio se na $5 \%$ ukupne vrijednosti poljoprivredne proizvodnje. Izvješće Odbora za poljoprivredu o Prijedlogu zakona o lovstvu, P. Z. E. br. 339, dostupno na: <http://www.sabor.hr/izvjesce-odbora-za-poljoprivredu-s-rasprave-o-0006>, očitanje 19. listopada 2018. 
u odnosu na štetu koju divljač počini na šumi i šumskom zemljištu. Naime, kako je već istaknuto, šume i šumska zemljišta ZOŠ-om određeni su dobrima od interesa za Republiku Hrvatsku te uživaju njezinu osobitu zaštitu. ${ }^{83}$ Ovakvim određenjem ZL-a onemogućava se zaštita i očuvanje funkcije šuma kao načina ostvarivanja interesa Republike Hrvatske u upravljanju šumskim ekosustavima proklamiranim u članku 6. stavku 1. toč. 2. ZOŠ-a. U konkretnom slučaju dolazi do izražaja spomenuta mogućnost kolizije u ostvarivanju posebnih vlasničkopravnih uređenja na području lovišta. Pritom, zakonodavac nije jasno istaknuo kriterije zašto je određenom vlasničkopravnom režimu dao prednost u odnosu na drugi. U konkretnom slučaju može se postaviti i pitanje dopuštenosti ograničavanja prava vlasništva u širem smislu. Zakonsko ograničenje prava vlasništva, u cilju uspostave posebnog pravnog uređenja za dobra od interesa za Republiku Hrvatsku, da bi bilo dopušteno, potrebno je da ispunjava pretpostavke predviđene Ustavom RH. Posebno uređenje mora se odnositi i na stvari koje Ustav RH određuje da su od interesa za Republiku Hrvatsku i da imaju njenu osobitu zaštitu, da je način uporabe $\mathrm{i}$ iskorištavanja tih stvari određen zakonom, da je zakonom određena naknada vlasnicima za ograničenja kojima su podvrgnuti posebnim pravnim uređenjem te da je ograničenje vlasništva razmjerno naravi potrebe za ograničenjem. ${ }^{84}$ U konkretnom slučaju, postavlja se pitanje koja potreba i u kojem razmjeru se zadovoljava ne priznavanjem prava na naknadu štete nositeljima vlasničkih ovlaštenja na određenim vrstama stvari koje ujedno predstavljaju dobra od interesa za Republiku Hrvatsku? Svakako da izneseno zakonsko uređenje može predstavljati osnovu za pokretanje postupka ocjene suglasnosti ZL-a s Ustavom RH pred Ustavnim sudom Republike Hrvatske zbog povrede temeljnih sloboda i prava čovjeka i građanina, odnosno nepovredivosti vlasništva.

\subsection{Vlasništvo $i$ raspolaganje trofejima ${ }^{85}$ i dijelovima divljači}

U odnosu na pravo vlasništva nad trofejima ZL određuje posebna ograničenja raspolaganja. Iz dikcije članka 74. stavka 1. ZL-a trofej kao dio divljači pripada lovoovlašteniku ulovom, ranjavanjem ili uginućem divljači. Međutim, trofej divljači koji podliježe vrednovanju ${ }^{86}$ mora se i ocjenjivati. Trofej divljači iz Republike Hrvatske dopušteno je iznositi uz propisani trofejni list, dok je vrhunski trofej divljači ${ }^{87}$ zabranjeno trajno iznijeti iz Republike Hrvatske. Vrhunski trofej divljači od vlasnika otkupljuje Republika Hrvatska prema odštetnom cjeniku koji donosi ministar nadležan za lovstvo, a čuva se u lovačkom muzeju Hrvatskog lovačkog saveza. ${ }^{88}$

83 Čl. 2. st. 1. ZOŠ.

84 Gavella, N. i dr., Stvarno pravo, str. 367-368.

85 Lovačke su trofeje, u užem smislu riječi, određeni dijelovi tijela ulovljenih krupnih vrsta divljači koje se ocjenjuju i vrednuju te koji nam mogu poslužiti kao pokazatelji njihova općeg stanja u lovištu te kvalitete staništa i provedenih gospodarskih mjera. Frković, A. i dr., Lovstvo, Zagreb, Hrvatski lovački savez, 2004., str. 460.

86 Način ocjenjivanja i vođenja evidencije trofeja divljači propisuje pravilnikom ministar nadležan za lovstvo. Čl. 71. st. 4. ZL.

87 Vrhunski trofej divljači je trofej koji je ocijenjen većim brojem bodova od najjačeg evidentiranog trofeja (prvaka) pojedine vrste divljači u Republici Hrvatskoj. Čl. 7. st. 1. toč. 28. ZL.

88 Čl. 72. st. 2. ZL. 
Divljač i njeni dijelovi podliježu i posebnim zakonskim ograničenjima u odnosu na prijenos ili prijevoz ${ }^{89}$ Naime, nakon što se stekne vlasništvo divljači prisvojenjem ulovom, divljač i njezini dijelovi smiju se držati, prenositi ili prevoziti uz potvrdu o podrijetlu divljači i njezinih dijelova, dok se ocijenjeni trofej divljači smije držati, prenositi ili prevoziti samo uz trofejni list. Potvrdu o podrijetlu divljači i njezinih dijelova izdaje lovoovlaštenik, odnosno korisnik površine na kojoj je zabranjeno ustanovljivanje lovišta..$^{0}$ Može se postaviti pitanje stvarne potrebe za visokim stupnjem regulacije prometa divljači i trofeja kao prepreke pravnom prometu koji je preduvjet za proklamirani razvoj gospodarske, turističke i rekreativne funkcije lovstva.

\section{OGRA円IVANJE LOVIŠTA}

Jedno od pitanja koje se pokušalo riješiti donošenjem ZL-a jest postavljanje granice lovišta, odnosno donošenje pravila o ograđivanju lovišta. Naime, utvrđivanje granica lovišta označava do kuda u prostoru doseže pravna vlast ovlaštenika prava lova u odnosu na nekretninu ${ }^{91}$ koja je lovište. Također, ograđivanje lovišta obvezatno je radi provedbe lovnogospodarske osnove, odnosno programa uzgoja divljači. ${ }^{92}$ ZL razlikuje otvorena lovišta, ograđena lovišta i uzgajališta divljači ${ }^{93}$ Pravila o ograđivanju lovišta, u tom smislu, razlikuju se od pravila iz ZV-a i Zakona o državnoj izmjeri i katastru nekretnina, ${ }^{94}$ kojima se određuje obveza vlasnika nekretnine da obilježi granicu svoje nekretnine ${ }^{95}$ Budući da se lovište može ustanoviti na zemljištima koja su u vlasništvu više različitih fizičkih i pravnih osoba tako se ne moraju podudarati oznake međašnih znakova i oznake granica lovišta. Isto tako je moguće da doseg vlasnikove pravne vlasti određen međom koincidira s granicom lovišta, odnosno dosegom nositelja ovlasti prava lova. U tom smislu, za utvrđivanje granice lovišta podredno se mogu primijeniti pravila iz članka 103 . ZV-a o načinu uređenja međe. ${ }^{96}$ Naime, i sam ZL

89 U tom smislu, u odnosu na divljač i trofeje divljači jasno je da se radi o stvarima ograničenim u prometu, budući da se iz socijalnih i gospodarskih razloga prometna sposobnost ovih stvari ograničava, odnosno podvrgava posebnom režimu prometa. Klarić, P. i dr., op. cit., str. 74.

90 Čl. 75. st. 3.-5. ZL.

91 Gavella, N. i dr., Stvarno pravo, str. 650.

92 Čl. 13. st. 4. ZL.

93 Otvoreno lovište ne može biti ustanovljeno na manje od 1000 ha, iznimno može se ustanoviti na otoku ili skupini otoka površine veće od 500 ha, te na zemljištu u vlasništvu pravne ili fizičke osobe, minimalne površine od 500 ha. Ograđeno lovište obuhvaća površine na kojima postoje uvjeti za intenzivan uzgoj, zaštitu, lov i korištenje divljači, a ne može biti manje od 1000 ha. Uzgajalište divljači je lovište minimalne površine od 100 ha državnog ili privatnog zemljišta na kojem se mogu uzgajati pojedine vrste divljači za uzgoj većeg broja divljači namijenjene lovu i razmnožavanju. Čl. 12. st. 2.-5. ZL.

94 Zakon o državnoj izmjeri i katastru nekretnina, NN br. 112/18. - dalje ZDIK.

95 Tako ZDIK u čl. 46. određuje obvezu nositelja prava na zemljištu na području na kojemu se provodi katastarska izmjera ili tehnička reambulacija da vidljivim trajnim oznakama na svoj trošak označi granice zemljišta, na kojemu imaju pravo vlasništva ili druga prava ili kojim upravljaju. ZDIK.

96 Sud će među obnoviti ili ispraviti prema katastarskom nacrtu, ako je to moguće i ako na to stranke pristanu. Ako nije u stanju postupiti na taj način, sud će među obnoviti ili ispraviti prema 
u članku 13. određuje da ako se granice lovišta ne mogu odrediti prema kriterijima određenim ZL-om moguće ih je odrediti i na drugi način. ${ }^{97}$ Međni znakovi, u tom smislu, izuzetno su pogodni, budući da predstavljaju dijelove nekretnine (npr. stijena, stablo, građevina i sl.), ili posebno postavljene međne znakove (međne kolčiće)..$^{98}$ Ovo osobito zbog zahtjeva iz članka 13. stavka 4. ZL-a da granice lovišta moraju biti vidljivo obilježene.

Vlasnici nekretnina koje graniče s površinama na kojima ima divljači imaju obvezu provođenja mjera za sprječavanje šteta koju divljač prouzroči svojim djelovanjem na poljoprivrednim kulturama, domaćim životinjama, gospodarskim ili drugim objektima. U tom smislu imaju obvezu ograđivanja zemljišta, ali i drugih mjera u svrhu zaštite svoje imovine od nastanka takve štete. ${ }^{99,100}$ Oštećenik koji ne poduzme mjere kojima se sprječava nastanak štete ili odstrani objekte (npr. ogradu) koji služe za sprječavanje šteta nema pravo na naknadu štete koju prouzroči divljač. ${ }^{101}$

\section{NAKNADA VLASNIKU ZEMLJIŠTA ZA OGRANIČENJA NA TEMELJU PRAVA LOVA}

Vlasnici zemljišta na kojima je ustanovljeno lovište u različitom su položaju s obzirom na intenzitet i sadržaj posebnih ograničenja koja se vlasniku nameću na temelju ustanovljenja lovišta. Najmanji stupanj ograničenja postoji u slučaju kada je vlasnik zahtijevao ustanovljenje lovišta samoinicijativno na svom zemljištu, tj. kada se radi o privatnom lovištu. Tada se on dobrovoljno podvrgava ograničenjima svog vlasništva. I kod ustanovljenja privatnog lovišta, spajanjem više zemljišta privatnih vlasnika, postoji mogućnost da vlasnik zemljišta bez slobodne odluke bude podvrgnut ograničenjima temeljem proglašenja zemljišta lovištem. ${ }^{102}$ Kod ustanovljenja državnog ili zajedničkog lovišta i bez pristanka vlasnika njegovo zemljište se podvrgava posebnom pravnom režimu što za vlasnika rezultira ograničenjima u korištenju i posjedovanju nekretnine. ${ }^{103} \mathrm{Za}$ ograničenja kojima je podvrgnut u ostvarivanju prava lova drugih osoba, vlasniku zemljišta bez prava lova određuje se naknada. ${ }^{104}$ Sredstva

sporazumu susjeda čija je međa u pitanju, a ne bude li postignut sporazum, prema posljednjem mirnom posjedu, a ne uspije li ga utvrditi - prema pravičnoj ocjeni. Čl. 103. st. 2.-3. ZV.

97 Granice lovišta moraju biti uočljive, a određuju se, ovisno o prirodnoj cjelini, ekološkim, geografskim i drugim uvjetima, obalnim pojasom mora i autocestama koje sprječavaju prirodnu migraciju dlakave divljači. Ako se granice lovišta ne mogu odrediti u ovom smislu, određuju se željezničkim prugama, županijskim i lokalnom cestama, putovima, vododjelnicama, rijekama ili na drugi način. Čl. 13. st.1.-2. ZL.

98 Gavella, N. i dr., Stvarno pravo, str. 651.

99 Čl. 79. st. 1. toč. 2. ZL.

100 ZL navodi radnje i zahvate za sprječavanje štete u lovištima kao što su ciljano čuvanje dobara, istjerivanje divljači, upotrebljavanje mehaničkih, električnih i kemijskih zaštitnih sredstava koja je na zahtjev oštećenika dužan osigurati lovoovlaštenik. Čl. 79. st. 1. toč. 2. ZL.

101 Čl. 79. st. 2. ZL.

102 Ako vlasnik zemljišta ne podnese zahtjev za ustanovljenje privatnog lovišta u roku određenom ZL-om njegove površine će se pripojiti lovištima u skladu s odredbama ZL-a. Čl. 16. st. 7. ZL.

103 Gavella, N. i dr., Stvarno pravo - posebna, str. 558.

104 Čl. 19. ZL. 
za predmetnu naknadu vlasnicima zemljišta bez prava lova izdvajaju se, odnosno prikupljaju, u skladu s člankom 31. ZL-a. ${ }^{105}$

Činjenica je da su vlasnici zemljišta na kojima se ustanovljuje zajedničko lovište podvrgnuti znatnim ograničenjima zbog ostvarivanja prava lova lovoovlaštenika. Tako je vlasnik zemljišta dužan trpjeti da nositelj prava lova, kao i osobe kojima on to dopusti provode na njegovom zemljištu sve radnje koje predstavljaju gospodarenje lovištem i divljači, što prije svega znači ovlaštenje na neposredan posjed zemljišta. ${ }^{106}$ S druge strane, za vlasnika zemljišta, u pravilu, to znači da mu je prilikom lova i lovnih aktivnosti onemogućen neposredan posjed zemljišta zbog prirode korištenja njegovog zemljišta od strane lovaca (upotreba vatrenog oružja). Također, vlasnik zemljišta ne može slobodno odlučivati o drugoj namjeni svoga zemljišta ako ono ispunjava preduvjete da bude ustanovljeno lovištem. ${ }^{107}$

Treba se kritički osvrnuti na okolnost da pravo na naknadu vlasnici zemljišta bez prava lova ostvaruju tek podnošenjem zahtjeva za isplatu naknade za tekuću lovnu godinu. ${ }^{108}$ Naknada se isplaćuje iz sredstava ostvarenih naknadama za koncesiju prava lova i iz zakupnine koje plaćaju lovozakupnici. ${ }^{109}$ Iznos naknade ZL ne vezuje za procjenu tržišnih vrijednosti ograničenja vlasničkih ovlaštenja, odnosno procjenu umanjenja tržišne vrijednosti zemljišta temeljem ograničenja nastalih ustanovljenjem lovišta. ${ }^{110}$ Naknada se vlasnicima zemljišta bez prava lova isplaćuje tek na njihov zahtjev. Pritom su vlasnici zemljišta vezani prekluzivnim rokom za zahtijevanje isplate naknade. ${ }^{111}$ Rok u kojem se može podnijeti zahtjev za isplatu naknade za tekuću lovnu godinu je od 30. rujna do najkasnije 30. ožujka. Nakon isteka kojega će se sredstva naknade koristiti za financiranje razvoja i unapređenja lovstva. ${ }^{112,113}$

Postavlja se pitanje, ako su vlasnici zemljišta bez prava lova automatizmom ZL-a podvrgnuti vlasničkim ograničenjima zbog ostvarivanja prava lova drugih osoba, zašto istim zakonskim automatizmom vlasnici zemljišta bez prava lova nisu podvrgnuti ostvarivanju svojih ovlaštenja na isplatu novčane naknade, već ista ostvaruju samo

105 Tako se sredstva naknade raspoređuju na način da $10 \%$ sredstava pripada vlasnicima zemljišta bez prava lova, razmjerno površini koja je obuhvaćena lovištem za koje se uplaćuje naknada za pravo lova, preko proračuna županija i Grada Zagreba na čijem je području ustanovljeno lovište, $30 \%$ sredstava pripada državnom proračunu, $50 \%$ sredstava raspoređuje se u državni proračun na račun Ministarstva za financiranje mjera određenih ZL-om i aktima donesenim na temelju njega, 10 \% sredstava raspoređuje se na račun županija i Grada Zagreba za provedbu ZL-a.

106 Gavella, N. i dr., Stvarno pravo - posebna, str. 570.

107 Loc. cit.

108 Čl. 31. st. 2. ZL.

109 Sredstva naknade za koncesiju prava lova raspoređuju se i koriste u skladu s odredbama članka 31. ovoga Zakona. Čl. 41. st. 3. ZL.

110 Gavella, N. i dr., Stvarno pravo - posebna, str. 571.

111 Loc. cit.

112 Čl. 31. st. 2. i 4. ZL.

113 Također, i iznos naknade koja se raspoređuje vlasnicima zemljišta bez prava lova ovisi o iznosu sredstava koji su ostvareni naplatom naknada za koncesije i zakupnine, odnosno dinamici uplate ih sredstava u proračun, neovisno je li to dovoljno da se svim vlasnicima kompenzira naknada u visini tržišne vrijednosti ograničenja vlasničkih ovlaštenja. Gavella, N. i dr., Stvarno pravo - posebna, str. 571. 
temeljem zahtjeva? Nije nevažno i što se sredstva koja ne budu isplaćena vlasnicima zemljišta, koji zbog nepoznavanja svojih prava nisu potraživali novčanu naknadu u zakonom predviđenom roku, koriste za razvoj i unaprjeđenje lovstva, što u stvari znači da se novac opet zakonskim automatizmom vraća koncesionaru. Dakle, isti zakonski automatizam ne djeluje u oba smjera. Zbog toga se može zaključiti da opisano uređenje iz ZL-a nije u skladu s Ustavom RH proklamiranim načelom da svako ograničenje prava mora biti razmjerno naravi potrebe za ograničenjem $u$ svakom pojedinom slučaju. ZL, u tom smislu, ne uspostavlja ravnotežu u ostvarivanju prava lova i ograničavanju vlasničkih ovlaštenja, već korištenje zemljišta vlasnika bez prava lova od strane lovoovlaštenika postavlja kao imperativ.

\section{ZAKLJUČNA RAZMATRANJA}

Predmet je zakonske regulacije novog ZL-a gospodarenje lovištem i divljači. Novo zakonsko rješenje treba stvoriti pretpostavke za uvođenje više reda u lovstvu, uređivanjem odnosa između lovoovlaštenika i davatelja prava lova i preciznije uređenje privatnovlasničkih odnosa. Vlasnicima privatnih zemljišta omogućuje se osnivanje privatnog lovišta na predmetnoj površini te se omogućuje i udruživanje vlasnika zemljišta pri osnivanju privatnih lovišta. Uređenje odnosa na temelju prava privatnog vlasništva u lovstvu prepoznato je kao pretpostavka bržeg razvoja lovnog turizma te unaprjeđenja lovstva kao važne gospodarske grane.

Stvarnopravni režim unutar lovišta analiziran je kroz ograničenja koja se nameću vlasnicima zemljišta na kojima su ustanovljena lovišta. Ovo je od posebnog značaja s obzirom na činjenicu da su zakoni koji interferiraju sa ZL-om, ZOŠ i ZPZ, kao i sam ZL, novijega datuma, te je bilo nužno naglasiti njihove dodirne točke, ali i mjesta kolizije. Ograničenja vlasničkih ovlaštenja temeljem posebnih stvarnopravnih režima za poljoprivredna zemljišta, šumska zemljišta i lovišta sigurno predstavljaju razlog veoma maloga broja privatnih lovišta, čiji je udjel u ukupnoj vlasničkoj strukturi lovišta sveden na statističku pogrešku. Također, naslijeđene tendencije iz razdoblja prije društvenih promjena devedesetih godina prošlog stoljeća, ponajprije potpuna dominacija društvenog i suspektnost privatnog vlasništva, predstavljaju prepreku privatnoj inicijativi u ustanovljenju lovišta.

S druge strane, visoka normiranost ovog područja ukazuje da je lovstvo polivalentno i interdisciplinarno područje i upravljanje njime mora biti znanstveno i stručno utemeljeno, budući da se time ostvaruju i opći interesi. Zbog toga je zakonodavac i uspostavio posebno pravno uređenje koje djeluje ograničavajuće na ostvarenje vlasničkih ovlaštenja koja tendiraju zadovoljavanju uskih privatnih interesa. Posebna pravna uređenja vlasničkopravne odnose uređuju autoritarno, tako da oni ovise o tijelima javne vlasti koja u pogledu njih izvršavaju neka javna ovlaštenja. Zakonodavac je u odnosu na vlasničke odnose u lovištu to obilno i iskoristio.

U radu se ukazuje na okolnost da se na području lovišta susreću različiti vlasnički režimi, za lovišta, šume i šumsko zemljište, te za poljoprivredno zemljište svaki s posebnim stvarnopravnim uređenjem. Iz te komplicirane konstelacije pravnih odnosa na istom etnitetu proizašao je i specifični pravni položaj nositelja različitih 
vlasničkih ovlaštenja. Posebno je problematizirano pitanje stjecanje prava vlasništva na divljači, pitanje statusa divljači i trofeja divljači kao stvari ograničenih u prometu, isključenja mogućnosti naknade štete za šume i šumska zemljišta koja predstavljaju dobra od interesa za Republiku Hrvatsku te pitanje ostvarivanja proklamiranoga načela razmjernosti između ograničenja vlasničkih ovlaštenja i ostvarivanja prava lova u odnosu na iznose naknade koja se raspoređuje vlasnicima zemljišta bez prava lova.

Prikaz otvorenih pitanja koja se danas mogu postaviti na teorijskoj i praktičnoj razini, a o kojima bi zakonodavac trebao voditi računa pri uređenju prava lova može poslužiti i eventualnim de lege ferenda rješenjima vlasničkopravnih odnosa u lovstvu.

\section{LITERATURA}

\section{Knjige i članci}

1. Bajt-Vučevac, Vesna, Alegro, Antun, Žvorc, Zdravko, Razvoj hrvatskog zakonodavstva o lovu, Stočarstvo: Časopis za unapređenje stočarstva, vol. 50, 3/1996, str. 219-225.

2. Frković, Alojzije, Lovstvo, Zagreb, Hrvatski lovački savez, 2004.

3. Gardaš, Miro, Alebić, Tamara, The introduction of a dominant legal system for the regulation of hunting in Croatia in the second half of the 19th century, 7. Međunarodni znanstveni simpozij gospodarstvo istočne Hrvatske - vizija i razvoj, Osijek, 2018., str. $28-37$.

4. Gardaš, Miro, Haman, Daniel, Regalno pravo lova i lovno zakonodavstvo u Hrvatskoj kroz povijest, Zbornik radova sa naučnog skupa, Historija države i prava $\mathrm{BiH}$ - izazovi i perspektive, Tuzla, 2017., str. 283-298.

5. Gavella, Nikola i dr., Stvarno pravo, Zagreb, Narodne novine, 2007.

6. Gavella, Nikola i dr., Stvarno pravo - posebna pravna uređenja, Zagreb, Narodne novine, 2011.

7. Klarić, Petar, Vedriš, Martin, Građansko pravo, Zagreb, Narodne novine, 2006.

8. Kolar-Dimitrijević, Mira, Wagner, Elizabeta, Lov i plemstvo u Hrvatskoj i Slavoniji, Ekonomska i Ekohistorija: časopis za gospodarsku povijest i povijest okoliša, vol. V, $1 / 2009$, str. 44-58.

9. Poljoprivredna enciklopedija, Zagreb, Jugoslavenski leksikografski zavod, 1967.

10. Romac, Ante, Rječnik rimskog prava, Zagreb, Informator, 1989.

11. Savić, Šime, Pitanje naknade štete možemo promatrati dvosmjerno, Lovački vjesnik, 4-5/2018.

Odluke upravnih tijela

1. Republika Hrvatska, Ministarstvo poljoprivrede, klasa: 323-01/18-01/235, urbroj: 52511/1349-18-2 od 3. prosinca 2018.

Vrela s interneta

1. Izvješće Odbora za poljoprivredu o Prijedlogu zakona o lovstvu, P.Z. E. br. 339, dostupno na: $<$ http://www.sabor.hr/>, 15. listopada 2018.

2. Prijedlog zakona o lovstvu, dostupno na: <https://vlada.gov.hr/>, 15. rujna 2018., 20. listopada 2018.

\section{Pravni akti}

1. Pravilnik o agrotehničkim mjerama, NN, br. 142/13. 
2. Ustav Republike Hrvatske, NN, br. 56/90., 135/97., 8/98. (pročišćeni tekst), 113/00., 124/00. (pročišćeni tekst), 28/01., 41/01. (pročišćeni tekst), 55/01. (ispravak), 76/10., 85/10. (pročišćeni tekst), 5/14. (Odluka Ustavnog suda Republike Hrvatske).

3. Zakon o državnoj izmjeri i katastru nekretnina, NN, br. 112/18.

4. Zakon o lovstvu, NN, br. 140/05., 75/09., 153/09., 14/14., 21/16., 41/16., 62/17.

5. Zakon o lovstvu, NN, br. 99/18.

6. Zakon o lovu, NN, br. 10/94., 29/99., 76/99., 14/01., 4/02.

7. Zakon o poljoprivrednom zemljištu, $\mathrm{NN}$ br. 20/18.

8. Zakon o šumama, NN, br. 68/18.

9. Zakon o vlasništvu i drugim stvarnim pravima, NN, br. 91/96., 68/98., 137/99., 22/00., 73/00., 129/00., 114/01., 79/06., 141/06., 146/08., 38/09., 153/09., 143/12., 152/14., 81/15. (pročišćeni tekst), 94/17. (pročišćeni tekst).

10. Zakon o zaštiti prirode, NN, br. 80/13., 15/18. 


\title{
Davorin Pichler*
}

\author{
Summary
}

\section{NEW PROPERTY LAW REGIME OF THE HUNTING GROUND}

The new Hunting Act should create the prerequisites for introducing more orders in hunting by regulating relations between hunters and provider of rights of hunting and more precisely regulating private property relations as a prerequisite for faster development of hunting tourism and the promotion of hunting as a significant economic branch. The paper deals with the question of acquiring ownership rights on game, wild game and game trophies status as goods restricted in commerce. In the paper, subject of criticism is the legal solution of the exclusion of compensation for damage to forests and forest land as goods of interest to the Republic of Croatia and the proclaimed principle of proportionality between the restriction of ownership rights and enforcement of hunting rights. An overview of the open issues that the legislator should take into account in regulating hunting rights may also serve to possible de lege ferenda solutions in the regulating of the ownership relations in hunting.

Keywords: hunting ground; property; rights of hunting; game; land; fees.

\section{Zussamenfassung}

\section{NEUE SACHENRECHTLICHE REGELUNG DES JAGDREVIERS}

Das neue Jagdgesetz soll das Jagen in Ordnung bringen, indem es die Verhältnisse zwischen dem Jagdausübungsberechtigten und der Jagdbehörde regelt. Ebenfalls soll das Gesetz die privatrechtlichen Verhältnisse präziser regeln, weil das die Voraussetzung für eine schnellere Entwicklung des Jagdtourismus und die Förderung des Jagens als einer wichtigen wirtschaftlichen Branche ist. Der Beitrag problematisiert die Frage des Erwerbs des Eigentumsrechts auf das Wild, den Status des Wildes und der Jagdtrophäe als einer beschränkt verkehrsfähigen Sache. Kritisiert wird die Gesetzeslösung über den Ausschluss des Schadenersatzes für Wälder und Waldgrundstücke als Güter von Interesse für die Republik Kroatien sowie auch des Grundsatzes der Verhältnismäßigkeit zwischen den Eigentumsbefugnissen und der Ausübung des Jagdrechts. Die Darstellung offener Fragen, welcher der Gesetzgeber

* Davorin Pichler, Ph.D., Assistant Professor, Faculty of Law, J. J. Strossmayer University of Osijek; davorin.pichler@pravos.hr. 
bei der Jagdregelung Rechnung tragen müsste, kann als eventuelle de lege ferenda Lösung über eigentumsrechtliche Verhältnisse im Jagdbereich dienen.

Schlüsselwörter: Jagdrevier; Eigentum; Jagdrecht; Wild; Grundstück; Ersatz.

Riassunto

\section{LA NUOVA DISCIPLINA DI DIRITTO REALE DELLA CACCIA}

La nuova legge sulla caccia deve porre i presupposti per l'introduzione di maggiore ordine nella caccia mediante la regolamentazione del rapporto tra chi detiene la concessione di caccia ed il soggetto che la rilascia e deve regolare con maggiore precisione i rapporti di diritto privato quali presupposti di un più rapido sviluppo del turismo della caccia e del miglioramento della caccia quale ramo rilevante dell'economia. Nel lavoro si tratta della questione dell'acquisto della proprietà sulla selvaggina e circa lo stato della selvaggina e dei trofei di caccia quali cose la cui circolazione incontra limitazioni. Si critica la soluzione giuridica in base alla quale si esclude il risarcimento del danno per i boschi ed i terreni boscosi quali demanio della Repubblica di Croazia e la realizzazione del principio di proporzionalità tra la limitazione delle espropriazioni e la realizzazione del diritto alla caccia. L'illustrazione delle questioni aperte delle quali il legislatore dovrebbe tenere conto nel disciplinare il diritto alla caccia potrebbe servire anche per delle eventuali soluzioni de lege ferenda nei rapporti di proprietà.

Parole chiave: riserva di caccia; proprietà; diritto di caccia; selvaggina; terreno; risarcimento. 